\title{
4. Britain's monetarist experiment - initial setbacks followed by triumph
}

Although money supply targets were introduced in 1976, the Labour Government led by Mr James Callaghan honoured them as much in the breach as in the observance. The key policy problem in 1977 - as on so many occasions before and since - was how to reconcile domestic monetary priorities (as expressed in the targets) with exchange rate stability. Strong upward pressure on the pound emerged at various times in the year, obliging policy-makers to choose between exchange rate appreciation and above-target monetary growth. Until late in the year the Government tried to hold the pound down, both by heavy foreign exchange intervention and by cutting interest rates. As a result, the money supply target (which had been for growth in sterling M3 of between 9 and 13 per cent) was exceeded by a significant margin. Moreover, the very low interest rates reached in late 1977 gave a strong boost to credit demand, notably to the demand for mortgages. House prices rose sharply in 1978.

Because of these monetary developments, the economy grew quite strongly in 1978 and early 1979, and inflationary pressures gathered momentum. The Conservative Government elected in June 1979 was very articulate about the need to reduce monetary growth and pledged itself to stick to its broad money target. By late 1979 it was clear that the only way this could be done was by a large rise in interest rates. Minimum Lending Rate (i.e., the old Bank rate) was raised to 17 per cent on 15 November. Because interest rates in other industrial countries were much lower, sterling became an attractive currency to hold and it appreciated strongly during 1980. By undermining industry's international competitiveness, the substantial currency appreciation was the immediate cause of a slump in the foreign demand for British products and a sharp fall in industrial output. Meanwhile the money supply target was again exceeded in the 1980/81 financial year, largely because of the abolition of an artificial scheme (the so-called 'corset' on bank liabilities) for limiting the size of banks' balance sheets.

By early 1981 the British economy appeared to be in a shambles. The slide in output and employment was the worst in the post-war period, while the new monetarist policy framework seemed far from working according to 
plan. Deep pessimism about Britain's economic prospects coincided with ritual media abuse of 'monetarism' as the 'ideology' which was to blame. The first piece in this section, 'When Balogh was wrong', reprinted from The Spectator of 14 March 1981, was intended as a corrective to the prevailing mood.

It pointed out that the German currency reform of July 1948 had also received a hostile reaction, particularly from the Oxford economics don, $\mathrm{Mr}$ (later Lord) Thomas Balogh, in a pamphlet published in April 1950. Five years later, in the midst of the German Wirtschaftswunder, Balogh's remarks seemed ludicrous. My point was that the critics of the 'Thatcherite monetarist experiment', such as commentators in The Observer and The Sunday Times, might look equally silly by 1985 . No one in Britain should have been surprised that a determined anti-inflation programme would have bad effects on output and employment in the short run. But the programme was medium term in nature and explicitly described as such (the 'Medium-Term Financial Strategy'). The commitment to responsible financial policies had to be for an extended period of time if it were to be convincing enough to change inflationary expectations.

Nevertheless, there was a need for a more considered discussion of the problems of 1980 and 1981, and I wrote two articles for The Banker on 'Why has monetarism failed so far?'. The first of these articles discussed the missed monetary targets and identified the buoyancy of bank lending to the private sector as the main culprit. As is obvious from my proposals for a medium-term financial plan (see pp. 55-65, especially p. 61), the strength of private sector credit in the early 1980 s surprised me.

The second article was concerned with the persistence of inflation despite severe monetary restraint. Part of the explanation was the long lag between monetary action and inflation response, but I highlighted another aspect of the problem. This was that monetary conditions had only indirect relevance for public sector inflation. Excessive pay awards in the public sector had therefore, in the article's words, been partly 'responsible for the poor unemployment-inflation trade-off' of the early 1980 s.

At no point in the early 1980s did I have any serious doubts about the validity of the Government's economic policies. Having been much influenced by Laidler and Friedman in the mid-1970s, I had always expected the pay-off to be over a long period, such as five or ten years. I did not realize how much damage the embarrassments and setbacks of 1980 and 1981 caused to the monetarist approach. Many of the politicians and officials who had supported monetary targets in the late 1970s decided that the events of the early 1980 s demanded a radical policy re-assessment. In the 1982 Budget Sir Geoffrey Howe indicated that the Government would pay more attention to the exchange rate and 'narrow money' in future. The retreat from mon- 
etarism had begun. I did not initially appreciate the full significance of these changes. ('Narrow money' consists of a limited range of monetary assets, either notes and coin alone (M0) or notes and coin plus bank deposits which can be used without giving notice (M1). It contrasts with 'broad money', which includes all bank deposits, including deposits with quite long periods of notice. Broad money had been the understood meaning of the phrase, 'the money supply', in the late 1970s.)

At any rate, broad money targets were retained in 1982, 1983, 1984 and early 1985. Inflation fell to an annual trend rate of 5 per cent and the path of output growth became more stable. As these years were quiet ones for the economy, the controversy about economic policy-making died down. Monetarism seemed to have triumphed. A crucial turning-point had been the reelection of Mrs Thatcher's Government in 1983, which appeared to make possible the continuity that the monetarist programme had always needed. There is no point denying that the 'Falklands factor' had been vital to the Conservatives' success in the 1983 election, and so to the durability of the monetarist approach. I noted the point in an article in The Spectator on 29 May 1982, 'Winning the economic war'. The two articles, 'Following Friedman' from The Spectator of 28 May 1983 and 'Alternatives galore, but none of them better' from The Times of 28 September 1985, celebrate the apparent achievements of monetarism in this relatively peaceful period.

\section{The Need for a Medium-Term Perspective}

From an article 'When Balogh was wrong' in The Spectator, 14 March 1981.

This article was a journalistic polemic, but it made the important point that ultimately successful programmes of financial control and market liberalization often appear to be failures in the short run.

The last two years of British economic policy have purportedly been an experiment in free markets and sound money. If the newspaper editorials are to be believed, the experiment is in a mess. Indeed, many leader-writers are saying that it should be abandoned as soon as possible and something more 'moderate' (usually left unspecified) put in its place. There is also a tendency to regard the British trial-by-monetarism as special and unique. This is wrong. Several countries have in the past followed economic programmes with similar intentions and methods. Some have lasted much longer than two years. What kind of mid-term reports did they receive?

Perhaps the most celebrated example of economic liberalization was the West German in 1948. Like its British counterpart today, it soon attracted 
comment and criticism. At almost exactly the same two-year stage now being reached here, an assessment of its progress was made by Thomas Balogh in a pamphlet entitled Germany: an Experiment in 'Planning' by the 'Free' Price Mechanism. The pamphlet, based on a talk given to a German trade union conference in April 1950, was published in Oxford in September of that year.

Before quoting from Balogh's little work, we should briefly describe the events it attempted to analyse. In July 1948, after a period in which some basic necessities could be obtained only by barter, the German Central Economic Administration introduced the Deutschmark in a comprehensive currency reform and abolished nearly all price controls. A consumer spendingspree developed which had a highly favourable effect in encouraging production, but also threatened rapid inflation. In November 1948 the central bank, then known as the Bank Deutscher Lander (later the Bundesbank), took conventional restrictive measures and adhered to them, with little intermission, for the next three years. Although production and exports continued to grow quickly, unemployment quadrupled between June 1948 and January 1950. In early 1950 unemployment averaged over 10 per cent of the labour force in West Germany as a whole, while in some regions it exceeded 20 per cent.

Balogh was scornful of the central bank responsible for this deflation. In his view, 'its leaders were hagridden by obsolete monetary theories'. Even worse, he thought, was the institutional framework created to stop politicians from meddling with monetary policy. The thinking behind the constitutional checks on political interference was 'a mixture of quaint opinions, those of the 19 th century on budget management and of the late Mr Montagu Norman on the proper role of a central bank'. Balogh admitted that production was increasing, but he doubted that the liberalization policy deserved any credit. On the contrary, 'the market mechanism is an exceedingly tardy and imperfect means of readjustment'. The policy would require continued deflation, even though this would be 'insufficient' to restore balance on trade with other countries. It was 'evident' that unemployment would 'not be permitted to decline much from the 1.25 to 1.5 million level'.

The pamphlet was not confined to purely economic issues, for Balogh was also despondent about Germany's political viability. The central weakness of the 'iniquitous new German economic and social system' was that the currency reform had favoured the rich at the expense of the poor. There was a resultant lack of the mass-consumption demand appropriate to the country's industrial structure. It followed that 'when the attempt is made to recreate mass demand and to wrench the productive system into another shape, a serious crisis and terrible social costs will be inevitable'. For this reason, the consequences of the currency reform were 'immense and immensely lamentable'. In Balogh's 
opinion, 'the reform had put money into the hands of hoarders and speculators, while the middle classes and workers had lost cash, confidence and respect for their conquerors'. He concluded that 'German society is less stable than ever'.

If Balogh was long on foreboding, he was not short of advice. 'Nothing but fast reform by free men can prevent the Western Germans from deserting political moderation for the militant extremes of right and left.' The first priority, according to him, was therefore an immediate co-ordinated reversal of economic policy. The choice was between further deflation and controls. As controls could be framed with the assistance of the trade unions and directed towards a more equal income distribution, they were clearly preferable. As for the autonomous central bank, that also should be brought under government supervision. Its independence would, according to Balogh, 'generate intolerable delays and frictions' in economic policy-making, 'the consequences of which menace political stability'. In short, Balogh wanted the German Government to desert the supporters of sound money and collaborate with the trade unions.

This may sound familiar to students of the British political scene in the last 20 years. It may, therefore, come as no surprise to the reader to learn that the Balogh who wrote such a fierce indictment of the German free market system in 1950 was the same Balogh who acted as personal adviser to Harold Wilson in the 1964-70 Labour Government, starred as an economic wizard in the Crossman diaries and was later given a life peerage for his services.

As it happens, the question of how Germany would have responded if its Government has taken his advice is not one of the might-have-beens of recent economic history. The assumedly crass, myopic and incompetent free market did rather well. Industrial production rose five times in the ten years after the currency reform, while the unemployment total dropped to 350,000 and the unemployment rate to 2 per cent. The allegedly archaic monetary ideas of the Bank Deutscher Lander were quite good at achieving financial stability. In the five years to 1955 the German price level went up by about 1 per cent a year, and trade surpluses were recorded continuously from 1952 onwards. On the whole, the Germans are probably glad that their rulers ignored Balogh's denunciation of their experiment in "planning" by the "free" price mechanism'.

If anyone became unemployed as a result of German economic liberalization, it was the architect of the policy, Dr Ludwig Erhard. He was made redundant by its success. Throughout the 1950s he was in the rare and happy position, for an economics minister, of having almost nothing to do. Perhaps, he reflected, like Mae West, that too much of a good thing can be wonderful. 
But there was one point he had in common with Lord Balogh. He also wrote a book about German economic policy. Entitled Prosperity Through Competition, it was published in English in 1958 and contained several passages on the early years of the experiment. Criticism, even within Germany, had been heavy and sustained. The trade unions tried to organize a general strike on 12 November 1948 . Fortunately, they obtained little public support. But Erhard acknowledged that the trade unions were not the only critics,

as a glance at the newspapers of those days proves. 'Pessimism reigns everywhere', 'Erhard at the end of his tether', 'Chaotic picture of prices', 'Economists in favour of a return to planning', were some of the headlines. Even worse, perhaps, was that within the economy one side began to insult the other. Everyone was ready to ascribe the fault to someone else -industry to trade, trade to industry, the urban dweller to the peasants and vice versa.'

This also sounds familiar. It is the sort of stuff which one now finds every week in The Observer and The Sunday Times, the two newspapers which have most noisily and repetitively opposed the Government's economic policies.

It seems that contemporary comment on the West German free market experiment was, at the two-year stage, very similar to that on Britain's today. The contexts are, of course, quite different. It would be silly to claim that, because liberalization in West Germany was initially unpopular and eventually successful, it will also work here. The sad truth is that monetarism, like taking exercise, is only good for you if it hurts. At the moment it is hurting. Naturally enough, people are complaining and saying it must stop.

The one lesson we can draw from Balogh's 1950 pamphlet is that they are not necessarily right.

\section{Why did Monetarism have so much Trouble in the Early 1980s?: 1. The Missed Targets}

From an article 'Why has monetarism failed so far?: 1. The missed targets' in The Banker, March 1982.

The rapid growth of bank lending to the private sector in the recession of 1979-82 was unexpected. It was the principal reason that monetary growth exceeded target. The article blamed the vigour of the private sector's demand for credit on the interaction of financial deregulation with a tax system which was too friendly to borrowers. It therefore pointed an accusatory finger at such features of the tax system as full deductibility of business interest as an expense and of mortgage interest from personal incomes. Some of these aspects of the British tax system have subsequently been 
changed, with, for example, the 1984 Budget lowering the standard rate of corporation tax, and so making borrowing and leasing less attractive to companies.

Monetarism has received a great deal of criticism and even a certain amount of mockery over the last two years. A few months ago many journalists were deriding it as intellectual junk which, because of its association with the deepest recession since the 1930 s and the resulting unemployment, could never be salvaged. Although signs of a more cautious and ambiguous assessment are now emerging because of the tentative recovery in the economy, something has clearly gone wrong. There is no doubt that British economic policy has been broadly monetarist in character in recent years and that it has not matched its supporters' original expectations. Economists need to ask in what respects and for what reasons monetarism has failed so far.

Most indictments of monetarist policies have been marked by great vigour, but also a curious inconsistency. On the one hand, they have emphasized the Government's inability to meet its own targets. As heavy political capital was invested in sterling $\mathrm{M} 3$ and the public sector borrowing requirement as symbols of successful financial policy, the charge seems to be that the Government has been incompetent according to criteria it recognizes. On the other hand, the losses of output and employment in 1980 and 1981 have been condemned as too high a price to pay for too small a reduction of inflation. As the Government's main aim was to lower inflation and it never denied that higher unemployment might occur, this second charge focuses on a policy objective to which the Government did not - at least initially pay all that much attention. The critics' inconsistency arises because, if the financial targets had been met, their first point would not apply, but the jobless total would have been far worse and their second point even more emphatic. A logical anti-monetarist cannot simultaneously level both charges against official policy.

However, a monetarist sympathizer should consider each of the two problems. The missed targets and the mass unemployment have been equally embarrassing, if in different ways. Although the two disappointments are related, we shall examine only the failure to achieve monetary targets in the present article. This failure has been essentially in the operation of monetary policy. In a subsequent article [reprinted here on pp. 95-104] we shall consider the question of why the consequences of the particular monetary stance chosen by the Government have been so damaging for the 'real' economy.

There has been a persistent tendency to exceed official money supply targets in the last two years. Previously they were met, if not very convincingly. In 1978/79 sterling M3 went up by 10.9 per cent against a target band 
of 8 per cent to 12 per cent, and in $1979 / 80$ by 11 per cent against 7 per cent to 11 per cent. Only in $1980 / 81$, when sterling M3 surged by 20.9 per cent compared with another 7 per cent to 11 per cent target, did control disintegrate. Another large overshoot seems likely in $1981 / 82$. The main headache for the money supply managers in 1980/81 and 1981/82 was the obstinate refusal of private sector demand for bank credit to decline despite a very depressed economic background. Every new loan creates a new deposit and every new deposit counts in sterling M3. ${ }^{1}$ With bank lending to the private sector at record high levels, the sterling M3 targets were wrecked. This much is well known and familiar. What is far less certain is why loan demand remained and indeed remains - so buoyant.

There is a temptation to suggest an explanation merely by providing a narrative of events. The first sign of serious trouble came in August 1980 when, following the abolition of the 'corset' in June, the full scale of credit growth over the previous two years was revealed. This credit growth had been channelled into some very obscure interstices of the financial system and no one appreciated how large it had been. Most of it had gone to the corporate sector. Despite the ruinous impact on the money supply targets, the furore caused by the abolition of the corset had died down by early 1981 . With many observers confident that loan demand had begun to subside, Minimum Lending Rate was cut to 12 per cent in the March Budget. By September and October it was clear that, once again, the problem had been underestimated. Bank lending was surging forward at an underlying rate of over $£ 1$ billion a month, with personal sector borrowing for house purchase this time being the most dynamic element.

But to focus on the sequence of specific episodes which together constituted the Government's policy failure evades the serious issues. It implies that bank lending could have been curbed if the Bank of England had changed its tactics a little on one or two critical occasions. This is almost certainly an illusion. A persuasive explanation for the strength of loan demand should instead relate it to deep-seated structural characteristics of the economic system. As it happens, a good argument can be made that the credit boom of 1979 to 1982 was the culmination of powerful trends which had been working, although often artificially suppressed, for over 30 years. To understand these trends it is necessary to recall Britain's economic situation in the 1950s and $1960 \mathrm{~s}$.

In those years the Government's priority was to raise economic growth by encouraging investment. A succession of legislative changes gradually improved the tax advantages of owning capital assets. Capital allowances of 100 per cent on plant and machinery became accepted by the early 1970 s and, in the November 1974 mini-Budget, the principle was extended to 
stocks as well. These changes were designed to stimulate the acquisition of real assets, if necessary by the incurral of paper liabilities. Other characteristics of the fiscal system, notably the tax deductibility of interest payments, were of long standing, but strengthened this effect. With inflation rates creeping upwards, the attractions of holding real assets increased further. Interest payments became equivalent to early repayments of capital, but they had the merit that a proportion of the cost was effectively borne by the Exchequer. There was a gradual spread of understanding about the most efficient methods of minimizing tax bills and maximizing protection against inflation. The answer, as more and more people realized, was to borrow money and invest in goods or property.

The combination of more worthwhile government investment incentives and rising inflation expectations generated a growing demand for credit. The problem had already surfaced by the mid-1950s. At that time, with economic policy subordinated to the need to maintain a fixed exchange rate, an early consequence of excessive credit expansion was to cause a run on sterling. A characteristic 'stop-go' pattern developed. Rapid credit growth would lead to a sterling crisis, forcing the introduction of direct restrictions on bank credit. As the balance of payments convalesced, these restrictions would be withdrawn and another burst of credit would be unleashed, only to end in another sterling crisis.

There was a definite incoherence in official policy. Repeated statements were made by politicians, businessmen and financiers on the need to increase investment and raise Britain's position in the league table of economic growth. Tax legislation was progressively altered in response to this clamour. By the mid-1970s Britain's investment incentives were the most generous of any advanced industrial nation. But the Government did not allow companies or individuals to take full advantage. Whenever the private sector began to invest heavily, imports of capital goods jumped and the balance of payments went into deficit. Quantitative restrictions on bank credit would then be imposed, neutralizing the effect of the investment incentives. There was a continuous unsatisfied demand for credit which would have passed through the banking system if it had been free to do so. The favourable tax treatment of investment collided head on with the monetary authorities' desire to restrain bank credit.

Quantitative limits on bank lending in the 1950s and 1960s had several harmful consequences. They handicapped banks subject to them, particularly the clearing banks, in their rivalry with other banks; they penalized the banking system as a whole in its competition with non-bank financial intermediaries; and they obstructed the efficient distribution of credit to profitable borrowers prepared to pay high interest rates. The concept of 'financial repression' has been proposed by Professor McKinnon, an American econo- 
mist who specializes in developing countries' monetary systems, to describe how government interference with interest rates and credit allocation can hamper economic growth by reducing total investment and directing the investment which does occur to the wrong places. Britain is not a developing country, but an argument could be made that its economy suffered from several features of financial repression throughout the stop-go era.

Because of the restrictions on the banks, the demand for credit was met by other institutions. Medium-term finance was available from the capital markets, with new debenture issues being particularly active in the late 1960s. Mortgages for house purchase were provided by building societies, while hire purchase companies and finance houses answered the personal sector's need for consumer credit. The banks continually lost ground to these other intermediaries.

In 1971 the Bank of England, with the full approval of the Government and most academic economists, decided that the process had gone too far. The Competition and Credit Control reforms were intended to put banks and non-banks on a more equal footing in their struggle to capture an increased share of financial intermediation. All restrictions on bank credit were abolished. Over the two years from September 1971, bank lending to the private sector doubled and was largely responsible for two consecutive years of 25 per cent money supply growth. The rapid monetary growth lay behind a powerful boom in economic activity, which by late 1973 was causing sharp deterioration in Britain's overseas payments position. The authorities reverted to direct quantitative restrictions on banks' balance sheets by introducing the 'corset'. Although specified in terms of deposit liabilities, the corset's aim and, to some extent, its effect - was to check the expansion of bank lending.

But the Competition and Credit Control reforms had not been entirely pointless. Although lending to the personal sector, a boom area in 1972 and 1973, showed little growth in the mid-1970s, the banks' entry into the market for medium-term finance was a permanent change. Whereas in the 1960s a company requiring medium-term finance would try to raise money through a debenture issue, in the 1970 s its first step was to apply to a bank. The character of banks' liabilities adjusted to this innovation in their lending. An increasing proportion of their deposits was 'wholesale' money, typically with a one-month or three-month term, in contrast to the traditional current accounts and seven-day deposits. The banks were so successful in satisfying the need for medium-term credit facilities that the debenture market was snuffed out. Partly as a result of the Competition and Credit Control reforms, the banks had taken opportunities for financial intermediation away from the capital markets.

Between 1973 and 1980 the banks continued to be subject to a range of official interferences which hampered their expansion. The most obtrusive 
was the corset, which was in force, if over three separate phases, for more than half the period from December 1973 to June 1980. But also important were qualitative guidelines discouraging credit to the personal sector, including loans for house purchase. As a result, the building societies' expansion was - almost without interruption in the 1970 s - at a faster rate than the banks'. Apart from these direct constraints on banks' balance sheets, they also suffered from the costs of the reserve asset ratio and, like other businesses, from the exchange control regime. The reserve asset ratio obliged them to keep part of their assets in relatively unprofitable investments, while exchange controls prevented them from lending in sterling overseas. In addition, the clearing banks suffered from the minor irritation of having to maintain $1^{1 / 2}$ per cent of their eligible liabilities in non-interest-bearing balances at the Bank of England.

Since 1979 all these regulations have been scrapped. The third instalment of the corset was withdrawn in June 1980. The circumstances in which this occurred were very humiliating for both the Bank of England and the Government when it became known that sterling M3 had risen by 5 per cent in July. The 1980/81 money supply target was ruined by just one month's figures. The banks concluded that the corset would never be imposed again. In consequence, they felt free to market their corporate lending facilities even more aggressively than they had done in the 1970s, with leasing being one new area of business which showed particular promise. The ending of all restrictions on lending to companies in 1980 was followed by the ending of nearly all restrictions on lending to persons in 1982. No formal announcement was made, but the banks were given to understand that they would be allowed to give mortgage finance to house-buyers, while more conventional personal sector borrowing would no longer be hindered. The distinction implicit in many earlier Bank of England announcements, between wicked lending to persons for consumption and benign lending to companies for investment, seemed to have been forgotten. Other reforms also expanded the banks' opportunities for business. The abolition of exchange controls in October 1979 gave them the chance to lend sterling to foreign borrowers. Initially most loans were directed to foreign banks in the Eurosterling market, but there has been an increasing tendency to direct funds to ultimate borrowers through syndicated credits. This development was certainly unexpected when the Conservatives came to power in May 1979, but even more so was the outcome of the debate on monetary control. Although its theoretical focus was supposed to be the merits of monetary base control, its practical effect was to remove regulations on bank balance sheets. The reserve asset ratio and the $1^{1 / 2}$ per cent cash requirement on the clearing banks lapsed in August 1981. 
Although informal understandings about banks' appropriate liquidity norms remain, these changes have left the British banking system relatively little burdened by central bank superintendence of its assets. In most countries the central bank enforces direct restrictions on the amount and the allocation of new lending business; in the United States and West Germany, two countries where such restrictions are absent, banks are required to maintain central bank reserves much above their true business needs. The contrast between either arrangement and the existing very liberal regulatory framework in Britain is sharp. It is not hyperbole to say that banks in Britain now operate in a freer and more relaxed environment than anywhere else in the world.

The sequence of liberalization moves between 1979 and 1981 may be interpreted as the second stage of a process begun by the Competition and Credit Control reforms in September 1971. Their motivation was to establish equality of competition between different kinds of financial intermediary, as it was felt - notably by senior Bank of England officials - that the quantitative bank lending limits of the 1950s and 1960s had unfairly penalized the banks and benefited their rivals. The great freedom currently enjoyed by the British banking system has arisen as a reaction to the excessive, if rather spasmodic and diffident, interventionism which characterized the 40 years until 1979.

Before 1971 the gradual increase in investment incentives provided by the tax system was not fully translated into credit growth because of crude quantitative controls on bank lending. Between 1971 and 1973 the banks were free from restraint - and the result was monetary bedlam when the Heath Government botched 'the dash for growth'. Interventionism, although in a milder form than before 1971, was renewed between 1973 and 1979. Since 1979 all restraints have been taken away. The precise date at which the new freedom began is open to question. Arguably, the ending of exchange controls in October 1979 was the turning-point because it rendered the corset ineffective as a device for controlling bank credit. (Banks merely lent to British companies from an offshore branch, bypassing the controls on their domestic activities.) But in some ways the August 1981 changes, in conjunction with the virtual demise of official guidelines against personal sector credit, were more important.

In the 1950s and 1960s there was persistent - and indeed growing incompatibility between the ever more helpful tax treatment accorded to purchases of plant, equipment, houses and other capital assets, and the authorities' anxiety about the damage to the balance of payments from excessive credit growth. Over the last two years this incompatibility has been progressively reduced. It is now non-existent. Here, in a nutshell, is the explanation for the bank credit boom of 1979 to 1982 . Whereas the credit demands fomented by the tax system were for long either frustrated or 


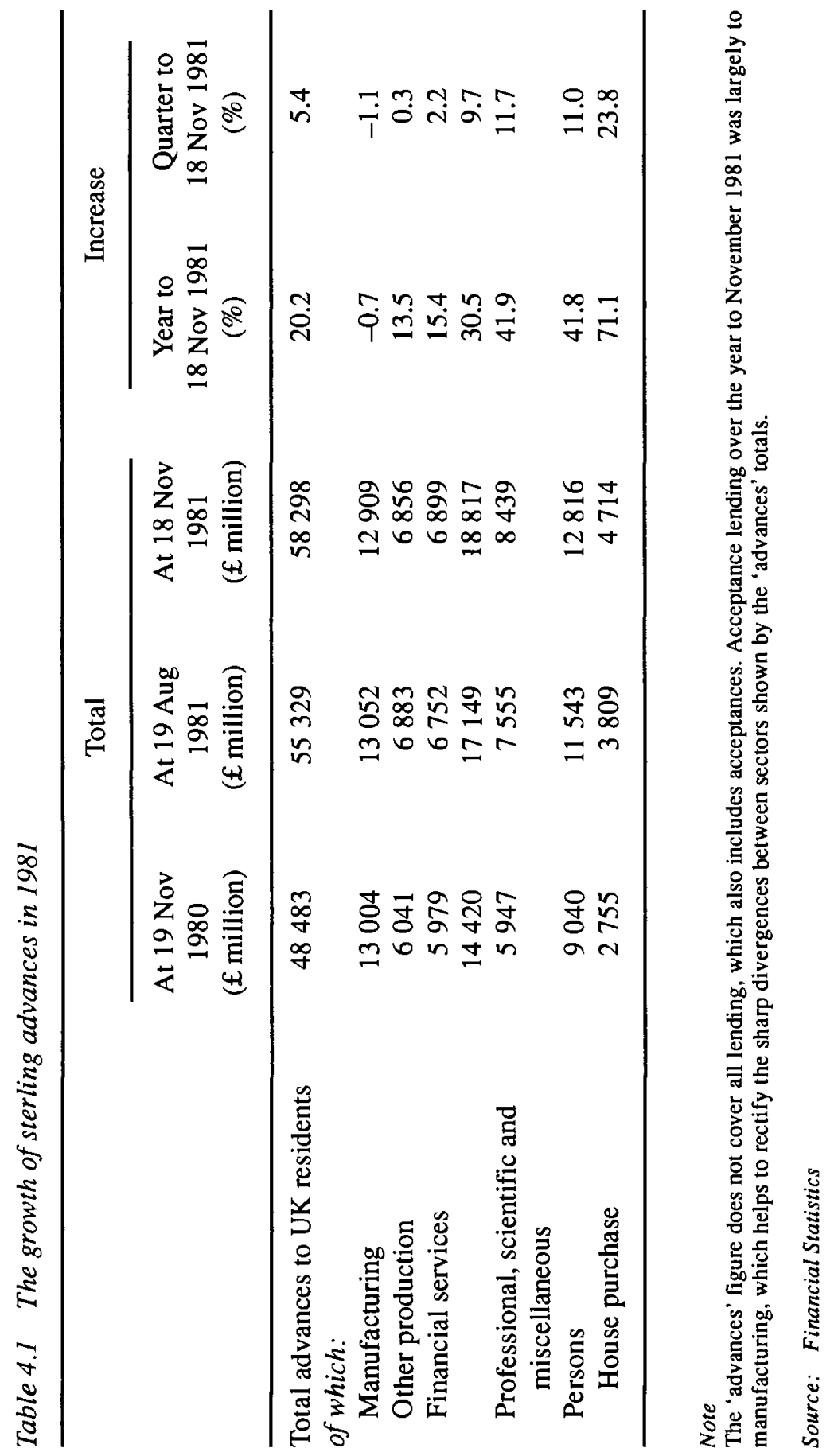


channelled through non-bank intermediaries, over the last two years they have passed through the banks. There is no sign that these credit demands are fading away. On the contrary, they seem to be accelerating. In the three months to January, sterling bank lending to the private sector and overseas was increasing at about $£ 2$ billion a month. This may somewhat overstate the underlying position, but a trend figure of $£ 20$ billion a year is not a wild exaggeration. The outstanding total of sterling bank lending at the end of the third quarter of 1981 was about $£ 72$ billion. It follows that, if the $£ 20$ billion a year figure is right, banks' loan books are currently growing by nearly 30 per cent a year.

Heavy emphasis has been placed in this article on the tax system as a prime culprit for the lending boom of 1979 to 1982 . Can this be substantiated by the evidence? Have tax-sensitive types of credit seen the most rapid expansion in the last two years? Some relevant statistics are given in Table 4.1. It shows how different sectors' bank advances increased over both the year and the quarter to the mid-November 1981 make-up day. This quarter is particularly interesting as it was the first after the final liberalizing changes last August.

The salient feature is the wide variation between the borrowing behaviour of different sectors. Advances to manufacturing industry barely changed in the two periods under consideration. Manufacturing has always been deemed a virtuous activity, high on the list of government priorities. As a result, loans to it have not been thwarted by official restrictions, and there was no major backlog of suppressed credit demand at the end of 1980. The 'other production' and 'financial' categories also registered quite moderate growth rates in 1981 , with a tendency towards deceleration.

There were only two conspicuous growth areas - 'services' and 'persons'. But the expansion of loans to the service sector was driven by one particular sub-category, 'professional, scientific and miscellaneous'. Over the year to mid-November this sub-category went up by 41.9 per cent and in the final quarter by 11.7 per cent, equivalent to an annual rate of 55.7 per cent. 'Professional, scientific and miscellaneous' sounds like a rag-bag and so appears to say nothing about the business motivation behind the loans. But the explosive growth of this type of lending is almost entirely attributable to one constituent - leasing.

The detailed logic behind leasing is quite complicated, but its essence is simple. An industrial company which is investing as much as its taxable profit cannot reduce its tax bill further by increasing capital expenditure. It has fully exploited the fiscal incentives for investment. But a financial institution, such as a clearing bank, benefiting from high interest rates, may have a taxable profit much above the sums needed for its own investment programme. Of course, if the financial institution could buy capital goods, it 
could cut its tax bill as effectively as the industrial company. The solution is for the financial institution to buy capital goods and to lease them to the industrial company which needs them.

The rental charged in the lease has two elements, one amount to recover the capital outlay and another which represents the rate of interest due on the investment. Because the financial institution receives a 100 per cent capital allowance, its tax bill (at a 52 per cent corporation tax rate) is halved and this interest rate may be 8 per cent rather than the 16 per cent implied by 14 per cent base rate plus a margin. Leasing has created, in effect, a market in tax allowances. It is clear that all bank loans which result from it are a byproduct of the tax system and, in particular, of the exceptionally favourable treatment of investment.

The amount of new lending for leasing purposes is difficult to estimate precisely, but it is a plausible surmise that it accounted for $£ 500$ million to $£ 600$ million of the additional advances to the 'professional, scientific and miscellaneous' sub-category in the quarter to mid-November. At that stage it was growing at an annual rate of about 60 per cent. In 1982/83 new lending for leasing may approach $£ 3$ billion, which by itself would cause a $3^{1 / 2}$ per cent increase in sterling M3. Against tax-subsidized opponents like these, money supply targets of 5 per cent to 9 per cent, or even 7 per cent to 11 per cent, are hopelessly outnumbered. There is also no chance of a revival of the debenture market. From the leasing subsidiary of a clearing bank, a company can obtain medium-term finance at 8 per cent or 9 per cent (sometimes fixed rate); from the capital markets similar money would cost 16 per cent.

Although leasing is growing quickly, far more public comment has so far been directed at the banks' entry into housing finance. The figures in Table 4.1 indicate why. In the three months to mid-November bank advances for house purchase rose by almost a quarter. At present they are running at about $£ 300$ million a month or $£ 31 / 2$ billion a year, again very large in relation to official money supply targets. Part of the reason for such heavy borrowing by individuals is the tax benefit of having a mortgage. As is familiar, all interest on a mortgage up to $£ 25,000$ can be deducted from taxable income. However, this is not altogether persuasive as an explanation because many bank loans for house purchase are bigger than $£ 25,000$. Continuing expectations of house price appreciation above the rate of interest, combined with the amenity value of living in a larger home, seem to have been the main influences on the heavy demand for mortgage finance. As building society lending has not fallen much, the big increase in funds channelled to the housing market appears to be attributable to the removal of official restrictions on the banks.

The buoyancy of lending for leasing and house purchase, both responding to tax advantages, confirms our thesis. The credit boom of 1979 to 1982 was 
caused by the liberalization of the financial system interacting with a fiscal regime designed to promote investment. Its origins are to be sought in two characteristics of the British economic debate in the 1960s - widespread dissatisfaction with the repercussions of quantitative bank lending restrictions on the efficiency of financial intermediation; and a very general anxiety about the presumed link between low investment and low economic growth.

The Government's failure to meet its money supply targets has almost nothing to do with its refusal to introduce monetary base control, as many academic monetarists, particularly from the American Mid-West, believe. These academics often seem to regard monetary base control as a universal panacea, regardless of the local context. As we have seen, the causes of the missed targets are instead parochial and specific; they can be understood most easily by an economist who has followed British governments' persistent tendency, over many years, to pursue irreconcilable economic objectives with a great deal of noise, enthusiasm and naivety. (Ironically, the Conservatives' record in controlling the monetary base is immaculate. In the period from June 1980 to November 1981 it increased by 3.1 per cent, compared with 29.6 per cent for sterling M3. It is since June 1980 that academic monetarists have complained most loudly about the Bank of England's supposed incompetence and blamed it on the absence of monetary base control machinery.)

The question arises of what the Government should have done at the beginning of the whole process. Surely, critics might claim, the Treasury and the Bank of England are full of clever people who should have realized that financial liberalization would cause the release of pent-up credit demands and a switch of business towards the banks, which together would lead to rapid growth in bank deposits and the destruction of official sterling M3 targets. Perhaps these clever people should have realized, but no one outside these institutions foresaw what was coming.

In fact, the authorities were in an impossible dilemma. The sequence of reforms introduced from October 1979 (the abolition of exchange controls) to August 1981 (the ending of balance sheet requirements for the banks) were all desirable. Whereas the financial system was subject to quite severe restriction for most of the 40 years to 1979 , it is now exceptionally free from government regulation. There is much evidence from developing countries that liberalizing the money side of the economy has favourable effects later on the 'real' side. ${ }^{2}$

But suppose that in mid-1979 Sir Geoffrey Howe, aware that liberalization would cause a credit boom, had said: 'Our sterling M3 targets in 1980/ 81 and $1981 / 82$ will be 13 to 17 per cent and 12 to 16 per cent. These are much higher than recent rates of increase, but reflect the distortions arising 
from a number of forthcoming measures intended to strengthen competition in the financial system, and should not jeopardize the Government's objective to achieve a lasting reduction in the rate of inflation. We cannot measure the distortions exactly, but believe they will be large'. Who would have taken the statement seriously? How could a government, publicly branded as monetarist, have announced that it would allow an acceleration of money supply growth?

Of course, neither Sir Geoffrey Howe nor his cohorts of advisers inside and outside the government machine appreciated in advance the potential scale of the 1979 to 1982 bank lending explosion. As a result, the presentation of policy has suffered a heavy blow. One objective of the Medium-Term Financial Strategy, declared in the 1980 Budget, was to mould inflation expectations favourably by projecting a gradual deceleration in target money supply growth in future years. That objective has not been fulfilled. But there have been pluses as well as minuses. It was because of the MediumTerm Financial Strategy that the Government raised taxes so vigorously in the 1981 Budget, a very courageous move which has had the effect of making Britain's public sector finances stronger than most other industrial countries'; and it was because money supply targets were in being that the authorities kept interest rates so high for so long. Without these interest rates, credit and money growth would have been even faster - and inflation would not now be heading for single figures. The decision to keep interest rates at such levels was broadly correct.

If the argument of this article is right, there will continue to be severe difficulties in reconciling money supply restraint with a free financial system, a tax system promoting investment and high inflation expectations. Because of the benefits a free financial system gives to the real economy, it would be a mistake to return to the interventionism of the $1950 \mathrm{~s}$ and $1960 \mathrm{~s}$. Arguably, the tax system is too friendly to investment and is the main culprit for the recent credit boom. Its reform might make some contribution to solving the problem of monetary control.

\section{Notes}

1. The implied approach to monetary control is to regulate the credit counterparts to bank deposits. This approach, which is broadly that adopted by the Bank of England, is very different from the banking multiplier theory found in the textbooks and academic monetarist writings. An account of how the credit counterparts approach works (if not very well) is given in T. G. Congdon, Monetary Control in Britain (London: Macmillan), 1982.

2. There may be a connection between the $1979-82$ credit boom, relatively high capital investment and the recent rapid growth of productivity. The possibility was analysed in 'The boom in bank Iending: is it related to the surge in productivity growth?', accompanying the 22 January 1981 issue of Messel's Weekly Economic Monitor. 


\section{Why did Monetarism have so much Trouble in the Early 1980s?: 2. The Public Sector Problem}

From an article 'Why has monetarism failed so far?: 2. The public sector problem' in The Banker, April 1982.

The article had a straightforward argument. One weakness of monetary control as an antidote for inflation is that it has little effect on the public sector. Since the Government can extract resources from the rest of the economy at will (by taxation or printing money), it has no need to hold money balances. There is no particular connection between monetary growth and public sector inflation. The large size of Britain's public sector (relative to, say, the USA) was therefore one reason for both the obstinacy of the British inflation problem in the 1970s and for the severity of the 1980/81 recession.

The Conservative Government may have failed to control the money supply, but it has succeeded in curbing inflation. The 1981/82 pay round seems likely to finish up in the 6 per cent to 8 per cent area. It will be the lowest since the $1977 / 78$ round, which was artificially and unsustainably depressed at the tail-end of an incomes policy. There can be little doubt that underlying inflationary pressures are weaker now than at any time since the late 1960s.

But has this achievement been bought too dearly? Over the last three years the unemployment total has climbed to three million, while hundreds of thousands more have at some stage or other been worried that they also might find themselves without a job. Too small a reduction in inflation seems to have been gained at too great a cost in terms of lost employment. Moreover, this failure does not matter only to the competing monetarist theologians who have bickered incessantly about the rival merits of different money supply definitions and agonized over the vagaries of sterling M3. It has directly affected many ordinary people. Most of them have no interest in the technical mechanics of monetary control and can be plausibly represented as the innocent victims of a government policy they do not understand. Surely, the critics argue, if monetarism works so badly there must be a better alternative.

There are two ways a monetarist might attempt to answer this charge. The first is to say that no one knows what determines the unemployment-inflation trade-off. But, whereas the Government cannot in the long run control the level of unemployment (which depends on labour market institutions), it is responsible - again in the long run - for the level of inflation (which depends on the central bank's regulation of the money supply). This cogent, but highly pessimistic, interpretation of the economic system was implicit in 
Friedman's 1967 exposition of the 'natural rate of unemployment', given as a presidential address to the American Economic Association. The natural rate is that at which there is no tendency for wage increases either to accelerate or to decelerate. It is consistent with stable inflation. 'Unfortunately,' Friedman warned, 'we have as yet devised no method to estimate accurately and readily the natural rate of unemployment." ${ }^{1}$ The corollary was that active attempts to manipulate unemployment beneath the natural rate would lead to ever higher inflation. The right approach was therefore to confine monetary policy to its proper role of achieving price stability. The unemployment repercussions, however dire, would have to be ignored.

The second response is more equivocal. It recognizes that the unemployment-inflation trade-off can be affected by government policy. According to this line of monetarist thinking, the key variable to operate on is inflation expectations. The reasoning is straightforward. If people expect low inflation, the adjustment of behaviour to a fall in inflation from a high level is easy and painless. On the other hand, if they expect rapid inflation, the same adjustment not only takes time, but also tends to be accompanied by setting the 'wrong' prices in product and labour prices. These 'wrong' prices include excessive wages, which then lead to unemployment.

Monetarism was never intended as a form of corporal punishment on the British economy. No one wanted unemployment to reach three million and, as is clear from forecasts made in 1979 and 1980, no one expected it to do so. Whatever some Sunday papers may say to the contrary, all monetarists would have preferred the unemployment-inflation trade-off to be more favourable. The question arises of what went wrong and whether anything could have been done to improve the situation. The argument of this article is that a very important cause of the adverse unemployment-inflation relationship was the movement of public sector wages and prices in the first two years of the present Government's period in office. This suggestion may not by itself be new or controversial. But I want in this article to propose a perhaps more provocative extension: it is that monetary policy has almost no relevance (except at several removes) to the containment of public sector inflation. Original monetarist hopes that the inflation problem could be solved solely by reducing the rate of money supply growth were naive. Because the money supply prescription neglected the public sector, it was incomplete. This is the sense in which monetarism was not - and is not - enough. (Sir Keith Joseph wrote an influential pamphlet Monetarism is not Enough for the Centre for Policy Studies in 1978, which argued that control over government spending had to accompany monetary restraint, if inflation were to be brought down. But it did not highlight the problem of public sector wages.) 
If the moderation of inflation expectations is necessary to mitigate the unemployment arising from restrictive financial policies, the Government made its first mistake in the June 1979 budget. The increase in value added tax from 8 per cent to 15 per cent had an immediate effect on the retail price index and wage-bargainers regrettably decided to incorporate it in the 1979/ 80 pay round. This was despite the large accompanying cut in income tax. It should perhaps be said, in the Government's defence, that at the time there was a strong body of informed opinion behind a shift from direct to indirect taxation. For example, the Meade Committee Report for the Institute for Fiscal Studies recommended a big rise in VAT as one part of its proposal to introduce an expenditure tax.

But more serious than the VAT increase was the surge of public sector inflation from mid-1979 until early 1981. It had two aspects. The first was the deliberate raising of public sector prices above the general rate of inflation. In the year to August 1980 the increase of the prices of goods and services produced mainly by the public sector was 26 per cent, while the retail price index as a whole went up by just over 16 per cent. The second was the tendency to grant public sector wage increases much higher than those in the private sector. The evidence on this point is abundant and persuasive. According to official figures published in the Treasury's December 1981 Economic Progress Report, the ratio of public to private sector earnings rose from $101.5(1970=100)$ in 1979 to 108.4 in 1981. An independent assessment in the August 1981 National Institute Economic Review had earlier reached similar conclusions.

Retrospective moralizing always sounds smug and patronizing. In this case, it is particularly unhelpful. To say that the Government should have controlled public sector pay and prices better in 1979 and 1980 is all very well, but it shows little appreciation of the local and specific justifications for excessive public sector inflation in those two years. The justifications were usually sound and sometimes compelling. It would have been difficult for any government, even one commanding widespread public support, to resist them. As it happened, the Conservative Government did not command such support and had to acquiesce in numerous pay and price changes it disliked.

The objections to holding down nationalized industry prices were both microeconomic and macroeconomic. In the last two years of the Callaghan administration there had been a politically-motivated failure to raise these prices. A consequent danger was gross resource misallocation with demand being inappropriately encouraged in areas where goods were supplied at beneath cost. The size of the required price adjustment was further aggravated by the second oil shock which pushed up energy bills. Nearly all the nationalized industries in Britain are either energy suppliers or highly sensitive to 
the price of energy. In addition to the need to prevent microeconomic distortion, the Government was worried that, if nationalized industries kept prices too low, their deficits would rise and jeopardize its goal of reducing public sector borrowing. Whatever the short-run once-for-all impact on the retail price index from higher nationalized industry charges, a macroeconomic priority was to cut the PSBR as part of the long-run strategy to contain money supply growth and inflation.

If the economic logic behind big increases in public sector prices was convincing, the political expediency of large public sector pay rises was undeniable. The most awkward of these rises stemmed from the Clegg Commission's activities and affected the earnings of groups, such as the teachers, the civil servants and the local authority manual workers, who account for a high proportion of total public sector employment. As the Conservatives had agreed to honour the Commission's awards before the 1979 election, not much could have been done - without patent breaking of pledges - to avoid paying up. In the context of 1979 to 1981, which saw several major public sector strikes anyway, refusal to match the increases recommended by Clegg would have invited at best widespread disruption and at worst open confrontation between the Government and trade unions.

But, however good the reasons for particular public sector wage and price increases, the effect on inflation expectations was very unfortunate. Many nationalized industry price rises were intended to change relative prices, correctly reflecting a sharper increase in the cost of their inputs, like energy, than in other industries. But there is a tendency, particularly in a country as easily swayed by newspaper headlines as Britain, to interpret price movements in certain major industries as symptomatic of a general trend. When 25 per cent or 30 per cent rises in the price of electricity, gas, coal and so on were announced in late 1979 and the early part of 1980 , businessmen thought these were indicative of prospective changes in the absolute price level.

They therefore decided that there would not be much of a penalty, in terms of lost sales, if their own prices were hoisted by similar percentages. They soon discovered that they had made a miscalculation. In the second quarter of 1980 demand for nearly all kinds of industrial product collapsed. It was a classic example of government policy causing private sector decision-takers to set the 'wrong' prices. Similar forces were at work in the labour market. Employment in the public and private sectors can be readily differentiated as a matter of definition, but comparisons between the two are frequent and inevitable. Moreover, the functional dividing-line is rather blurred. Many unions are strongly represented in both and expect them to have similar wage levels, while job interchanges are quite common. When large public sector increases took place in 1979 and 1980, private sector employers felt obliged to give similar rises, irrespective of their own ability to pay. Once 
again the Government's approach to controlling public sector inflation was responsible for employers and employees deciding 'wrong' prices which, in this case, meant wage levels inconsistent with the preservation of jobs.

The term 'administered prices' has been suggested for those prices set less by market forces than by bureaucratic decision. Although it may be a misunderstanding to think that the prices of any product can be analysed without reference to supply and demand, there is little doubt that many public sector prices and charges are administered, at least in the sense that the people responsible are not much bothered by the subsequent effect on the quantity sold. The Government's programme to raise administered prices in 1979 and 1980 worsened inflation expectations. At the same time, monetary policy was being tightened to slow down the rise in market prices. The conflict between policy towards public sector administered prices and private sector market prices was total. There was a head-on collision between price-making behaviour in the two different parts of the economy. The smash contributed to the biggest increase in unemployment since the early 1930 s.

At this stage of the argument an academic monetarist might start to complain. Surely, he would say, the remedy for excessive public sector inflation is the same as for excessive private sector inflation. It is to reduce the rate of money supply growth. There is nothing special or unusual in the problem.

Here is the mistake. What the academic monetarist fails to understand is that much of the public sector is completely immune to tight monetary policy - or to lax monetary policy, for that matter. It is quite easy to identify mechanisms whereby a reduction in money supply growth checks inflation in the private sector. Slower money growth means that companies' bank deposits are not increasing as much as before; they may perhaps be rising at less than the going rate of inflation. If companies continue to raise wages and carry out investment plans on the same scale as previously their balance sheets come under strain. Their most liquid asset - their balance at the bank - may fail to grow in line with their liabilities, notably bank borrowings and trade creditors.

If this mismatch intensifies, they may be bankrupted. Measures to improve the bank balance are therefore necessary. Such measures may include cutbacks in stocks, lay-offs of workers and deferment of investment, all of which are likely to restrain price and wage increases. The nature of the link between a deceleration in money supply growth and slower inflation is fairly obvious in the private sector, whatever the controversy about its strength and timing. But compare this with the public sector. The civil servants in government departments who manage expenditure do not have to worry about a bank balance. They receive their money from the Treasury and the Treasury can borrow at will from the Bank of England. This power to borrow is, of 
course, equivalent to a licence to print Bank of England notes. The notes are legal tender and must be accepted as payment for goods.

It follows that most of the government sector does not have to keep bank deposits as a liquidity reserve to meet unexpected bills. It also follows that slower growth of the total amount of bank deposits has no effect whatever on those individuals whose daily task is to control government expenditure. Although monetary policy acts as a powerful constraint on (or stimulant to) businessmen in the private sector, it is useless and irrelevant as an instrument for influencing civil servants in the public sector. A reduction in the rate of money supply growth cannot solve the problem of public sector inflation. ${ }^{2}$ Indeed, the situation is rather worse than that. Suppose that the overall inflation rate is 16 per cent - with public sector inflation at 26 per cent and private sector inflation at 10 per cent. (This broadly describes Britain's position in mid-1980.) Unsympathetic journalists and Opposition politicians are bound to deride 'the failure of monetarism', the apparent inadequacy of monetary restraint as a method of lowering inflation; 16 per cent is, after all, a rather disappointing performance.

The only answer an academic monetarist could propose would be to reduce the money supply growth even more. But it is clear from the numbers what would happen. The private sector, already burdened by its inability to offer wages competitive with government employment and by higher electricity, gas, water, transport and other nationalized industry bills, would have to reduce its inflation rate to 8 per cent or 6 per cent. The imbalance between it and the public sector would be exaggerated. More companies would go into liquidation, more workers would join dole queues and, as long as the public sector pressed on with big wage and price increases, more gloomy inflation news would be announced. (This broadly describes Britain's position in early 1981.)

The academic monetarist might protest that money supply control does eventually feed through to the public sector. Government employees will, in their expectations about what constitutes a reasonable wage award, take note of settlements in the private sector, while the sales revenue of nationalized industries is determined largely by business conditions in the economy as a whole. These are fair observations. But there is an implied recognition that monetary policy has its direct and immediate effect on the private sector alone; it is afterwards that the public sector has to adjust. Even when the adjustment comes, it is not because of anxiety about balance sheets, liquidity, interest rates and so on; it is because of earlier anxiety about these variables by private sector decision-takers.

Indeed, a case can be presented that to control inflation in a mixed economy by monetary means is almost certainly unfair to the private sector. The inequity can be mitigated by such devices as 'cash limits' on public ex- 
penditure, set in accordance with money supply targets or expected private sector inflation. Another possibility is that a formal incomes policy may be more effective in the public sector than the private, helping to redress the discriminatory impact of monetary policy. ${ }^{3}$ Both cash limits and incomes policies can be regarded as virtuous confidence tricks, which would mould expectations favourably and help to stop the private sector setting the 'wrong' prices. Whatever the merits of these particular arguments, there is no doubt that textbook versions of monetarism - both as they were available in May 1979 and as they are available today - are silent about the problem of public sector inflation. This silence is symptomatic of a larger weakness in the monetarist position, a haziness about the precise transmission mechanisms by which changes in the money supply influence changes in the price level. Earlier in the article a brief account was given of how companies might be forced to take inflation-reducing action in response to balance sheet difficulties caused by slow money growth. But this was merely a sketch. In the real world there is a rich diversity of other mechanisms at work.

If the monetarist story is to be persuasive, it should explain how these interact with each other, which is the quickest to take effect, which is the most powerful and so on. Instead, monetarists seem to be preoccupied with what are termed 'reduced form' econometric exercises, which try to discover the relationship between one big number (money national expenditure) and another big number (the money supply), ignoring the thousands of little numbers in between. This habit is partly responsible for the tendency to look at the money national expenditure as a whole and to overlook the contrasting behaviour of its two constituents, public expenditure and private expenditure. ${ }^{4}$

A further dimension of the topic needs to be emphasized. Some influential monetarist research was carried out by the Manchester Inflation Workshop, under Professors Parkin and Laidler, in the mid-1970s. Two of its most insistent themes were that inflation was a monetary phenomenon and that what it termed the sociological school, which analysed wage increases in terms of relative bargaining power, was mistaken. ${ }^{5}$ The main drawback to the Manchester view is that it regards all wage increases as taking place in the same institutional environment, which is clearly incorrect. In the private sector, market forces are at work and monetary policy is the main determinant of inflation. But in the public sector, market forces are remote from the bargaining process. The money supply does not matter in settling the pay of civil servants, health workers, teachers and so on, but relative bargaining power does. There are economic techniques for analysing bargaining situations, but no definitive theory has been derived. So it is necessary, unfortunately, to pay attention to sociological variables like the political attitudes of 
trade union leaders. This is messy, untidy and not to the taste of rigorous monetary economists, but it is also the real world.

The waywardness of public sector inflation is a nuisance not merely for analytical reasons. It also gives rise to the serious practical question of how it should be controlled. If money supply restraint is not the solution, what is?

The major nationalizations and the establishment of a large permanent public sector were completed during the Attlee administration of $1945-51$. At that time Labour Party intellectuals had few doubts about the problem of public sector pay. Their judgement was that, with so much of the economy in state hands, it would be possible to replace arbitrary market forces by the sweetness and light of responsible centralized wage bargaining. They hoped that at long last incomes could be determined by the ideal of social justice. Ever since governments and trade unions have squabbled about what 'social justice' involves. For the particular producer group affected it normally means 'more for us' and 'less for them'. The determinant of public sector pay is not sweetness and light, but who is the bigger and better bully.

The downfall of the Heath Government in 1974, after a disastrous contest with the coalminers and narrow defeat in a general election, encouraged the belief that public sector unions are very good at bullying. The memory of this experience was largely responsible for the sharp improvement in the public sector's relative pay, both in 1974 and 1975, and in the period from 1979 to 1981 . It is no surprise that the present Government should have been worsted so badly. The advice it received from its friends was 'control of the money supply is sufficient for control of inflation'. They did not warn that control of the money supply is insufficient for the control of inflation arising in the public sector.

The solution, as more people have come to realize, is for the Government to strengthen its bullying position. There are, of course, many illustrations of the likely success of this course of action. In Communist countries, as there is only a tiny private sector, the problem of inflation reduces to the problem of public sector inflation. Governments maintain tight restrictions over the trade unions, which are merely accomplices of political repression, so that the risk of excessive wage demands is eliminated without further ado. In several Latin American countries, again with large public sectors, the power of independent trade unions has been smothered by military dictatorships.

If these examples are reliable, there is no difficulty about curbing inflation even given the dominance of public sector employment. The Government has only to make itself nasty enough. According to opinion polls, trade union leaders are very unpopular in Britain today. Any government, facing insubordination by a powerful public sector group, would probably command 
extensive support from the general public if it showed itself prepared to take the necessary counter-measures.

What are these counter-measures? So far British governments have displayed a certain lack of imagination about the methods available. Recently, however, Professor Meade has outlined some possibilities in his book on Wage-Fixing. A union which failed to accept the arbitration of an independent pay tribunal and went on strike should, Meade suggests, be subject to certain sanctions. These might include the withdrawal of the right to redundancy money, the impounding of union funds and the payment of supplementary benefits only in the form of loans. Once a government began to go down this path, it is difficult to see where it might stop. In the last resort, it could evict recalcitrant strikers from council houses or end their right to state pensions. If any union thinks that it is necessarily a bigger and better bully than the government, it is making a serious mistake. The record of many autocratic regimes in the Communist world and elsewhere is testimony to this melancholy but inescapable truth.

There is no easy solution to the problem of public sector inflation. A reduction in the size of the public sector would obviously make the area of potential dispute smaller. The implied recommendations are further denationalization and subjecting public sector employees to market disciplines similar to those already operating in the private sector. There might be disagreement about how these disciplines are to be specified, interpreted and applied, but the objective of parity of treatment in the public and private sectors seems reasonable. This approach might be criticized as too 'ideological'. But, if it is ideological to want to remove an active source of social tension which in many countries has contributed to the establishment of political tyranny, then 'ideological' is surely a term of approval.

Public sector inflation is a political issue and it can be tackled only by political means. The failure of monetarism in the last three years owes much to misunderstanding on this point. Monetary policy did curb private sector inflation. But, because public sector wages and prices rose quickly as a result of Government decisions, inflation expectations were stimulated and 'wrong' prices were set in many parts of the economy. This was responsible for the poor unemployment-inflation trade-off - and so for the increase in the jobless total to three million. The hope must be that in the next few years the trade-off becomes more benign. There are cases, such as West Germany in the early 1950s, where unemployment and inflation declined together. The exercise of restraint by public sector unions may be a precondition for a similar outcome in Britain in the mid-1980s. Much depends on the political situation, particularly the result of the next general election. 


\section{Notes}

1. The concept of the natural rate of unemployment was advanced in Friedman's 1967 presidential address to the American Economic Association. The paper, 'On the role of monetary policy', was reprinted in M. Friedman, The Optimum Quantity of Money (London: Macmillan), 1969.

2. The point was strongly emphasized on p. $\mathbf{5 8}$ of T. G. Congdon, Monetarism: an Essay in Definition (London: Centre for Policy Studies), 1978.

3. The sequence of 'on-off' periods of incomes policy can be interpreted in terms of the differential impact of monetary policy on the public and private sectors. See T. G. Congdon, 'The incomes policy cycle in Britain: an attempt at explanation', The Banker, December 1980.

4. The link between money and private expenditure is, however, noted on p. 30 of D. Smith, 'The counter-inflation strategy in historical perspective' in the London Business School's February 1981 Economic Outlook.

5. See, particularly, D. Laidler and D. L. Purdy (eds), Inflation and Labour Markets (Manchester: Manchester University Press), 1974.

\section{The Value of a Long-Term Anti-Inflation Programme}

From an article 'Winning the economic war' in The Spectator, 29 May 1982.

Because of the 'long and variable lags' between monetary restraint and lower inflation, about which Friedman warned so clearly, any successful anti-inflation programme had to last for several years. A crucial problem for the Thatcher Government in its first term was that it would run out of time, with not enough benefits emerging from its policies after five years to make its re-election possible. In this context the Falklands War of 1982 was a godsend. Some extraordinary and totally unexpected events in Argentina and the Falklands led to Mrs Thatcher's re-election, giving the monetarist programme the time it needed to work.

While the fighting has intensified in the South Atlantic, there has been a curious lull in hostilities on the home front. Critics of the Government's economic policies have gone rather quiet. It is not hard to explain why. The main weakness of the Thatcher experiment has been its time-scale. Sound money and free market policies have worked in many countries and on many occasions, but they have always taken a long time. In their early years programmes of economic liberalization can be very painful. Perhaps the most celebrated example, the Erhard currency reform of 1948, was considered as late as 1951 to have been a serious mistake for the West German economy. It was only in the mid-1950s that people began to talk about the Wirtschaftswunder.

The Thatcher Government's opponents have assumed that the British electoral term is too short. Many of them secretly admit that the policies 
would succeed if pursued with enough determination for a sufficiently long period, but they doubt the political staying-power of such an abrasive approach. Until two months ago they took it for granted that the Conservatives would lose their parliamentary majority in the next general election. The Thatcher experiment would therefore be scuttled before any of its benefits might emerge.

Now the position has changed. The probable outcome of the Falklands crisis would have been to strengthen the Government's popularity even if the Opposition had handled the affair with some degree of political competence. In the event the Labour Party has bungled terribly. As a result there is a distinct possibility that Mrs Thatcher will win the next general election and that the policies with which she is so closely identified will have the time they need to reach a favourable conclusion. There has also been helpful economic news. By chance the timing of the landing in San Carlos Bay coincided almost exactly with that of the announcement of the April retail price index. It showed a 9.4 per cent rise in the previous 12 months. The Government has achieved one of its symbolically most important objectives - single-figure inflation. Over the period to the general election the rate of price increases is likely to decelerate further.

Viewed from an historical perspective the cost of controlling inflation has been appalling. If an economist had been told in 1967 that there would simultaneously be three million unemployed and 9.4 per cent inflation 15 years later, he would have regarded the forecast as a macabre joke. But attitudes have shifted. From an electoral standpoint the crucial issue may prove to be not the level of unemployment, but the direction of change at the time voting takes place. Here, too, the trends are reassuring. The rate of increase in the jobless total has slowed down sharply in recent months. There is a good prospect that the numbers out of work will stabilize or start falling by early 1983 . With skilful editing of history and suitable phrasemaking about leanness and fitness, it may even be feasible to present 1980 and 1981 as a period of great advance by British industry. That would be a caricature, but a few marginal voters may be persuaded.

And what would happen if the Conservatives were re-elected in 1983 or 1984? It is an unattractive and perhaps a callous thought, but the three million unemployed would be a potential economic asset instead of a persistent electoral liability. The reason is that at some stage they will seek new jobs and so provide the manpower for a sustained period of rapid economic growth. In the 1950s and 1960s the binding constraint during the expansion phase of the stop-go cycle was invariably a shortage of labour, expressed in excessive wage increases. Because of the resulting lack of competitiveness there were frequent balance-of-payments difficulties. In the late 1980s there should be no labour shortages and no balance-of-payments difficulties. 
All this is a horrifying prospect for the tribe of leftish leader-writers, SDP activists, morally indignant trade union leaders and Sir Ian Gilmour, who have warned us so often that the Government's policies would end disastrously. Their favourite target has been 'monetarism', about the meaning of which they have, however, been a little vague. With the aid of certain Sunday newspapers they have led us to believe that the vagaries of sterling M3 have no effect on inflation, but are responsible for misfortunes as diverse as race riots in Brixton, inner-city problems in Toxteth and the threatened closure of aluminium smelters in Invergordon.

What proposals will the reflationists start peddling now? Will the realization that they are no longer on the offensive, force them to strengthen their analysis and add fresh bite to their polemic? The impression given by their most recent statements is that it will not. Take, for example, a column by $\mathrm{Mr}$ Peter Shore in The Observer of 23 May. He summarizes his recommendation as the replacement of 'passive government' by 'active government'. 'We shall,' so he says, 'have to plan for economic growth and industrial change, and intervene in the economy to achieve them... Human intelligence, with all its imperfections, must once more be brought to bear on the forces of the market.' He fills out his allotted eight hundred words with a few remarks about 'a range of measures' to rig interest rates, the exchange rate and the international flow of capital, but otherwise does not introduce any ideas of substance to his readers. Of course, no one would question the prerogative of politicians to write empty bluster like this. But there is at least an expectation that the bluster will be entertaining. The objection to Mr Peter Shore, Sir Ian Gilmour and their associates is not so much that they are wrong, but that they have ceased to be interesting. There is something risible about pontificating on the need 'to plan for economic growth and industrial change' nearly 20 years after George Brown set up the ill-fated Department of Economic Affairs.

Keynesianism became boring about 15 years ago, monetarism became boring about three years ago, and today the critics of monetarism have become boring too. In consequence, the economic debate is shifting from labels and terminology to weighing the advantages and disadvantages of particular institutional arrangements and policy approaches. Wreckage from earlier theoretical battles is still littered over the newspapers, but there is a developing consensus that the size of the budget deficit and the rate of money supply growth are important economic variables. Monetarism, if in a diluted and flexible form, is securely entrenched. Because of this, and signs that the economy is recovering without deliberate reflation, the Government will adhere to the broad outlines of its original strategy. There may be minor tactical adjustments here and there, but they will not amount to much. As the 
critics' arguments become more hackneyed and their language more dreary, the intellectual opposition will seem increasingly unconvincing.

It may seem ugly and even a little ghoulish to suggest that the Government's domestic policies will receive another chance as a side-effect of a military dictatorship's delinquent behaviour which has led to a silly war and unnecessary loss of life. When considered with detachment, the whole business is miserable and ludicrous. It should certainly not be a pretext for national selfcongratulation, let alone rejoicing. But as the cogency of the case for what Sir lan Gilmour calls 'the good old expansionary measures' is waning, it would not be too unjust if the Government's economic policies were allowed to continue and Mrs Thatcher was re-elected thanks to General Galtieri.

\section{A Confident Forecast of Prosperity in the Mid-1980s}

\section{From an article 'Following Friedman' in The Spectator, 28 May 1983.}

This article emphasized the obverse of the monetarist gloom about everrising inflation while unemployment was held beneath its natural rate. (See pp. 24-7, the article 'Price stability and the "natural" level of unemployment', reprinted from The Times of 22 January, 1975.) As long as unemployment remained above the natural rate, inflation would keep on falling. Indeed, it ought to be possible, in principle, to combine falling unemployment and lower inflation for a period. The argument was the basis for an optimistic forecast of the medium-term economic prospects. This forecast was, in fact, fully justified by the rapid output and employment growth, and moderate inflation, of the next five years.

Sadly, the remark in the penultimate paragraph (that 'We can rely on economic commentators to invent more adventurous programmes and so create a climate of opinion in which governments will tend to stray... from the narrow path of financial prudence') was also fully justified by events.

Until 1979 all post-war governments failed to achieve their economic objectives. The problem of how to reconcile financial stability, as indicated by the inflation rate and the balance of payments, with a strong 'real' economy, measured by output growth and the level of employment, proved too difficult.

The Thatcher administration, unlike its predecessors, has achieved its objectives. But this success has been made possible not by particular cleverness, skill or luck, but because it has redefined the economic problem. It has concentrated on the financial side and abandoned targets for the real economy. This approach, implicit from the start, was made explicit with the announce- 
ment of the Medium-Term Financial Strategy in March 1980. The strategy proposed gradual declines in the ratio of the budget deficit to national income and in the rate of money supply growth, with the eventual aim of a substantial reduction in inflation. Broadly speaking, that is what has happened. The budget deficit and money supply growth have been cut, and inflation is lower now than for 15 years.

The focus on financial targets had its intellectual origins in a theory advanced by Milton Friedman in his 1967 presidential address to the American Economic Association. He said that there was one rate of unemployment, the 'natural rate', towards which the labour market would settle in the absence of outside intervention. This was the only rate compatible with stable inflation. If any government misguidedly tried to drive unemployment beneath the natural rate, inflation would not be constant at a high level, but would accelerate explosively, culminating in hyper-inflation and the collapse of political life.

It followed that monetary policy should be confined solely to the task of maintaining price stability and should not be used to pursue an arbitrarilydefined full employment target. Friedman's argument was a radical challenge to the orthodoxy, dating from the 1944 Employment Policy White Paper, that governments had an overriding commitment to full employment. It was pessimistic, and widely understood to be pessimistic, in its denial that politicians could do much good by manipulating macroeconomic levers. But it was also optimistic in its underlying premise that, if unemployment rose above the natural rate, the economy contained innate mechanisms that would bring actual unemployment back into line with the natural rate. This optimistic strand has been almost unnoticed in public debate.

Mrs Thatcher herself has repudiated the notion of a natural rate of unemployment. In a House of Commons exchange on 26 March 1981, Mr Foot asked her, 'Will she explain what is meant by the "natural rate of unemployment" that Treasury spokesmen mentioned to a Select Committee? Is it not wrong to introduce the idea that there is a natural rate of unemployment of about 5 per cent?' She answered that, 'It is not a Treasury concept. It is an academic concept invented some time ago. I have never agreed with it or thought it sound.' The reply may not have been altogether frank. The concept with which she is supposed to have 'never agreed' is the only analytically rigorous and intellectually convincing justification for the single-minded concentration on financial variables which has been the hallmark of her administration's economic policy.

Mrs Thatcher's refusal to endorse the natural rate idea should be blamed not on ingratitude to her intellectual mentors, but on political circumspection. The phrase 'natural rate of unemployment' is objectionable because of its connotation that there is something pre-ordained and unavoidable about 
people being without jobs. No politician could ever admit this. Her preference has been to dress up technical economics with homespun morality. Instead of referring to the need for money supply restraint and a low public sector borrowing requirement, she talks about sound money and good housekeeping. For public relations purposes this is almost certainly right.

The Government has also benefited from a widespread recognition that unemployment stems from the elimination of industrial inefficiency. There is a great deal of common sense in this. Monetarism can be castigated for many things, but not for over-manning at Port Talbot, unofficial strikes at Halewood and bloody-mindedness at Liverpool Docks. People voted for the present Government because they wanted to stop the more eccentric tribal customs of the British trade union movement. It would have been naive to imagine that this process would not involve heavy unemployment, at least for a time.

The Government's record can be summed up briefly: in its first term it has done the dirty work either for its second term or for its successor. Rightly or wrongly, perseverance with sound finance and the closure of unproductive factories have created a pool of three million jobless workers. It is here, paradoxically, that we come to the optimistic side of the natural rate theory. The point is that the brute fact of mass unemployment has created labour market pressures - in the form of long job queues and passive union leaders - for a decline in inflation. While unemployment is above the natural rate, these pressures will persist. Indeed, unless unemployment falls to the natural rate, inflation will decelerate year after year until actual declines in the price level are recorded. This is the counterpart to the proposition that inflation will accelerate explosively if unemployment is beneath the natural rate.

There can be little doubt that in Britain today unemployment is above, possibly very much above, the natural rate. Wage settlements and inflation have been declining since late 1980 when the jobless total was one-and-ahalf million. So the natural rate of unemployment must be below two million. It follows, by the logic of Friedman's theory, that unemployment could go down by a million and there would still be a tendency for inflation to fall. The economy can look forward to the happy combination of lower unemployment and lower inflation.

A suggestion of this kind is regarded as fantasy by middle-of-the-road forecasters at organizations like the National Institute and the London Business School, which both establish and reflect the economic consensus. As far as they are concerned, the future is mostly an extrapolation of the past. Any suggestion that it might be much different is considered an imaginative indulgence. So their typical procedure when making a medium-term forecast is to examine the economic data for the last ten years, add them up, divide 
by ten and then assume that the resulting numbers will be average performance in the next few years.

Not much insight is required to see that, although this may be economic forecasting, it is not serious thinking. If the method were legitimate, any decade of economic history would closely resemble the decades before and after it. But economic history is not like that. The more optimistic assessment of current prospects generated by the natural rate theory is, unlike the standard forecasts, based on the idea that individuals' response to economic conditions varies as those conditions vary. For example, it appeals to the simple hypothesis that someone out of work will look for a job. Whatever the econometrics of the matter may be, this seems plausible as an observation on human nature.

The conventional economic forecast also suffers from an obsession with aggregates, big numbers like 'consumption', 'investment' and 'public expenditure'. It cannot easily handle the shift of manpower and investment from smokestack to sunrise industries which has been a feature of Mrs Thatcher's first period in office. Between June 1978 and September 1981, the numbers employed in metal manufacture fell by 31 per cent from 459,000 to 314,000 , while the numbers employed making computers rose by 42 per cent from 43,000 to 61,000 . In 1982 and 1983 the change in the relative importance of the two industries has continued and will improve Britain's long-term economic prospects. An econometric model which assumes that future output growth will be the same as the average of the last ten years, a period characterized by mindless subsidization of metal manufacture and the rest of Britain's supposedly 'essential industrial base', is very likely to be wrong.

The Conservatives have in fact been successful in strengthening the supply side of the economy. The rate of productivity increase has clearly improved relative to previous trends, particularly in manufacturing. There is an apparent irony here because the Government has, of course, placed most emphasis on sound finance and the fight against inflation. But there is no inconsistency. Evidence of the better productivity performance helps to legitimize a policy approach in which the Government takes responsibility for financial variables and abdicates from the management of the 'real' economy. It should be said, in partial qualification, that neither Sir Keith Joseph nor Mr Patrick Jenkin has ended the philanthropic activities of the Department of Industry, although these are possibly less misdirected today than they were four years ago.

If a commitment to sound finance has dominated the Conservatives' economic policy in their first term, and served them reasonably well, how should this commitment be maintained if they are elected for a second, third and fourth term? The logical completion of the Medium-Term Financial 
Strategy would be a balanced budget, a rate of monetary expansion always equal to the underlying growth rate of productive capacity and price stability. The Conservative manifesto does, indeed, refer - if rather sheepishly - to price stability as an ultimate objective. There is, however, a fatal weakness in this set of policies: they are so simple, straightforward and obvious that they would leave economic commentators with nothing to say. We can therefore rely on economic commentators to invent more adventurous programmes and so create a climate of opinion in which governments will tend to stray - every now and again - from the narrow path of financial prudence.

But, if occasional wobbles from sound money are an inevitable part of our economic future, that is still much better than our position in the past. In the 1960s and 1970s Britain was the chronic invalid of the industrialized West. The Thatcher administration's most salient economic achievement is to have restored a measure of financial self-respect. Sterling crises, like country lanes and historic inns, used once to be part of the British way of life. They will not be in the next five years if the Conservatives are re-elected on 9 June.

\section{A Perspective on a Decade of Progress}

From an article 'Alternatives galore, but none of them better' in The Times, 28 September 1985.

This was the last article I wrote which was strongly supportive of the Thatcher Government's economic policies. I still thought - wrongly in late 1985 - that the Government was committed to monetary control. My argument was that, despite many problems, the framework of financial control introduced by Healey in 1976 and consolidated under Mrs Thatcher had led to a signifcant improvement in Britain's economic circumstances. Over most of the period sterling $M 3$ had been the focus of monetary targeting. I urged that it be retained in future.

A craving for intellectual novelty does not improve economic policy. If people are to understand what the Government is doing, the framework of policy should be simple and stable. Frequent shifts from one framework to another weaken confidence that the Government believes in its own rules, undermine official targets and reduce the effectiveness of policy.

So much is obvious. But that has not stopped much hostile comment on the present approach to economic policy, with its emphasis on joint control of the budget deficit and money supply. The critics' most familiar refrain at the moment is that monetarism, sterling M3 and the public sector borrowing 
requirement have all, in their different ways, become 'meaningless'. Sometimes they claim that full British membership of the European Monetary System (EMS) would be superior to monetary targets; sometimes they say that fiscal policy should stabilize 'public sector net worth' (the difference between the public sector's assets and liabilities); sometimes they have no alternative to suggest. But they are agreed on the desirability of replacing current arrangements with something new. There is a danger that this sort of comment will be accepted uncritically merely because it has captured so many column inches and been repeated so often. It is important to check whether the existing system has performed well or badly.

Contrary to folklore, the system began in late 1976, not May 1979. In July 1976 Denis Healey, then Chancellor of the Exchequer, said that a money supply 'guideline' was to be followed. This was soon firmed up into a target. In December 1976 the Government announced a Letter of Intent to the International Monetary Fund (IMF) which contained conditions for domestic credit expansion and public sector borrowing. There have been targets for the PSBR and money supply growth ever since. A reasonable way of assessing the system is to compare the major economic indicators at about the time it was introduced with the same indicators today. The facts are summarized in Table 4.2. For every variable under consideration the situation is better now than it was a decade ago.

Table 4.2 Britain's economic performance: a comparison of the mid1970 s and the mid-1980s

\begin{tabular}{lcccc}
\hline & 1975 & 1976 & 1984 & 1985 \\
\hline Inflation - (\% increase in prices) & 25.3 & 15.0 & 4.9 & $5^{3 / 4}$ \\
Balance of payments - & & & & \\
$\quad$ current account as \% of GDP) & -1.6 & -0.7 & +0.3 & $+3 / 4$ \\
Output - (\% change in GDP) & -1.2 & +2.7 & +2.4 & $+3^{1 / 2}$ \\
Employment - (change in labour & -90 & -212 & +380 & +250 \\
\hline force, in '000s) & & & \\
\hline
\end{tabular}

Note

Inflation is increase in retail price index in year to fourth quarter; balance of payments is current account deficit/surplus as \% of GDP at factor cost, current prices; output is change in GDP as factor cost, average estimate, year over year; employment is change in employed labour force (inc. self-employed) from mid-year to mid-year.

Figures for 1975, 1976 and 1984 are actual; figures for 1985 are estimates based on recent experience and consensus forecasts.

Source: Economic Trends 
The improvement is clearest on the financial side. Inflation is down to about 5 per cent, only a quarter of the 20 per cent it averaged in 1975 and 1976. The balance-of-payments current account, at present in modest and satisfactory surplus, was then in significant deficit. Indeed, if we extend the period of comparison back to 1974 , the current account deficit amounted to almost 5 per cent of gross domestic product, the worst figure in our peacetime history.

Output and employment, the so-called real variables, have also behaved more favourably in the two years, 1984 and 1985 than in the two years, 1975 and 1976. Inflation and external payments figures in the mid-1970s were not the unhappy financial counterpart to a cheerful record of growth and employment. The employment total was falling steadily and at the end of 1976 the unemployment rate was at its highest since the 1930s. Although unemployment today is even worse, the numbers in work are rising. The increasing demand for labour reflects a well-defined and quite strong upturn in economic activity which should cause growth in 1984 and 1985 to be the highest in any two-year period since the Barber boom of 1972 and 1973.

Given the dreadful starting-point in the mid-1970s and the need to tame inflation expectations, the unemployment cost may have been inevitable. If any government had tried to cut unemployment by deliberate demand stimulus in the early 1980s, inflation and the balance of payments today would be worse. Unemployment might nevertheless be just the same because the government would be forced to halt and then undo the stimulus to prevent the financial variables running hopelessly out of control. This may sound like bold and untestable conjecture. It is certainly conjecture, but the experience of several European countries suggests that it is far from bold or untested. France, Italy, Spain and Ireland have all at various times in the last decade indulged in supposedly unemployment-reducing demand reflation. Today their average unemployment rate is above Britain's.

Their reflation had to be reversed for the sake of monetary rectitude, but inflation and the balance of payments remain poor. The evidence seems to be that financial policy is powerless to affect real variables in the long run, but that it can be effective in controlling financial variables. That is the precise thinking, the exact rationale, behind the original shift towards the new set of policy rules in 1976. Since the present system has a satisfactory track record, strong arguments have to be adduced if the Government is to abandon it. The benefits of joining the EMS, targeting public sector net worth or adopting seat-of-the-pants pragmatism are hypothetical and impossible to quantify. The benefits of the existing arrangements are known and substantial.

It would be particularly foolish to reject the PSBR and sterling M3 because the figures have generated problems of interpretation. Sterling M3 cannot be 'meaningless'. It consists of bank deposits, notes and coin, and no 
one in his right mind can believe that their holdings of these assets do not affect the behaviour of individuals, companies and financial institutions. The relationship between sterling M3 and national income wobbles from year to year and forces policy-makers to exercise discretion in monetary management. But it is about as wrong-headed for economists to claim that bank deposits are meaningless as it is for a meteorologist to dismiss the sun and moon as empty baubles.

The current approach to financial control has not been an unqualified triumph: it has not (yet) created a new Jerusalem of price stability and full employment. But neither has it been an absolute failure. The Government can fairly answer the critics by highlighting the advantages of PSBR and money supply targets. In particular, it can point to the facts and emphasize that the last decade has seen considerable improvement in Britain's economic circumstances. 